\title{
無電解 $\mathrm{Pd}-\mathrm{P}$ 合金めっきと析出皮膜の特性
}

\author{
本間 英夫*，進藤 義朗**，高木 㐤則*
}

\section{Electroless Pd - P Alloy Plating and Properties of the Deposited Film}

\author{
Hideo HONMA *, Yoshio SHINDO ** and Michinori TAKAGI *
}

$*$ 関東学院大学工学部 (

**関東学院大学大学院（干236 神奈川県横浜市金沢区六浦町4834）

* Fac. of Eng., Kanto Gakuin Univ. ( 4834 Mutsuura-cho, Kanazawa-ku, Yokohama-shi, Kanagawa 236)

** Graduate school, Kanto Gakuin Univ. ( 4834 Mutsuura-cho, Kanazawa-ku, Yokohama-shi, Kanagawa 236)

\begin{abstract}
概要＼cjkstart次覀リン酸ナトリウムを還元剤とする無電解 $\mathrm{Pd}-\mathrm{P}$ 合金めつきについて検討した。基本的な実験によ り，パラジウムイオンに対する錯化剤は，トリエチレンテトラミンが有効であった。また，めっき浴にタリウム イオンを添加することにより, めっき浴の安定性は向上した。析出速度は, パラジウムイオン濃度が増加するに したがって増加した。しかし, めつき浴の $\mathrm{pH}$, タリウムイオンやトリエチレンテトラミンの濃度は, 析出速度 には大きな影響は与えなかった。析出皮膜のリン含有量はめっき浴の $\mathrm{pH}$ が増加すると共に減少した。析出した 皮膜はめっき直後は, 非晶質構造であるが, $300^{\circ} \mathrm{C}, 2$ 時間の熱処理を施すことにより, $\mathrm{Pd}$ と $\mathrm{Pd}_{8} \mathrm{P}$ の結晶化 が起こった。はんだ濡れ性, 接触抵抗, 摺動性, 硬度, 応力および耐食性などの皮膜物性は, めっき浴にマレイ ン酸を添加することにより, 大いに改善された。
\end{abstract}

\begin{abstract}
Electroless $\mathrm{Pd}$ - P plating using sodium hypophosphite as a reducing agent has been investigated. From fundamental experiments, triethylenetetramine (trien) was found to be much preferable complexing agent to the palladium ions. High bath stability can be achieved by an addition of thallium (I) sulfate to the bath. Plating rate is increased with increasing palladium ion concentration, but the other parameters such-as $\mathrm{pH}$ value, thallium ion and trien concentration do not have great influence on the plating rate. It was confirmed that phosphorus content of the deposited film decreases with increasing $\mathrm{pH}$ value of the bath. Deposited film has amorphous structure under the as - plated condition and it is transformed into the crystals consisting of $\mathrm{Pd}$ and $\mathrm{Pd}_{8} \mathrm{P}$ by heating at $300{ }^{\circ} \mathrm{C}$ for $2 \mathrm{~h}$. Physical properties such as solderability, contact resistance, sliding friction, hardness, stress and corrosion resistance were greatly improved by an addition of maleic acid to the bath.
\end{abstract}

\section{1. 緒 言}

パラジウムは，金と同様高い耐食性を保持し，耐 磨耗性に優れているという性質から, リードフレ一 ムやコネクタへの金の代替めっきとして，近年その 要望が高まってきている。

リードフレームへは銀めつきを施す場合が多いが, ピンピッチが狭くなると, マイグレーションによる 事故が発生しやすくなる。そのため最近，パラジウ
ムめつきが，マイグレーション防止に適用されたり， はんだの下地めっきとしても注目されている1)。さら に, パラジウムの水素吸蔵性を利用し, 選択的に水 素を透過させる，水素精製膜などの研究が行われて いる 2 。これらの目的に対して, 従来は電気めつきに 関する研究が主であったが，不導体材料をはじめ金 属材料に対して, 微細で複雑な形状の部品へ均一性 に優れた成膜をするため, 無電解めつきの要求が高 まってきている。無電解めっき法によるパラジウム 
めつきについては，すでに縄舟らによる，エチレン ジアミンを錯化剤とした浴について一連の報告がな されている ${ }^{3) \sim 5)}$

本報では，無電解パラジウムーリン合金めっきの 基礎的条件を確立し, 不導体材料としてアルミナセ ラミックスを，また金属材料としては銅板をめっき 素地とし，これらの材料への成膜条件について検討 するとともに，析出皮膜の特性としてはんだ需れ性， 接触抵抗, 摺動接触抵抗, 硬度, 応力および而食性 試験について評価した。

\section{2. 実験方法}

本実験では，無電解パラジウムーリン合金めっき の基礎条件を確立すると共に，その析出皮膜の工業 的適応性を検討するために, 以下の項目について実 験を行った。

1 ）錯化剤の選定

2 ) 安定剤の選定

3 ）析出速度およびリン含有量の変化と析出皮膜 の形態

4）析出皮膜の熱処理に伴う結晶構造の変化

5 ）析出皮膜の物性
I）はんだ濡れ性
IV）硬度
II ）接触抵抗
V) 応力
III）摺動接触抵抗
VI）耐食性

無電解パラジウムーリン合金めっきの基本浴組成 およびめつき条件を表 1 に示す。

\section{1 錯化剤および安定剤の選定}

表 1 のめつき浴組成で, パラジウムと錯体を形成 すると考えられる錯化剤を用いてめっきを行い, 浴 の安定性を評価した。つぎに, 安定剤の濃度を $20 \mathrm{ppm}$ に統一し， 2 時間めっき後の浴の状態と析出皮膜の 外観から安定剤を選定した。

Table 1 Bath composition and plating conditions.

\begin{tabular}{cc}
\hline $\mathrm{PdCl}_{2}$ & $0.01 \mathrm{~mol} / \ell$ \\
$\mathrm{NaH} 2 \mathrm{PO} 2$ & $0.06 \mathrm{~mol} / \ell$ \\
Stabilizer & $10 \sim 20 \mathrm{ppm}$ \\
Complexing agent & $0.10 \sim 0.40 \mathrm{~mol} / \ell$ \\
$\mathrm{pH}$ & $5 \sim 8$ \\
Temperature & $60^{\circ} \mathrm{C}$ \\
Plating time & $1 \sim 2 \mathrm{~h}$ \\
Without agitation & \\
\hline
\end{tabular}

めつき素地としては無酸素圧延銅䇴を用い, $40^{\circ} \mathrm{C}$ の過硫酸アンモニウム $(100 \mathrm{~g} / \mathrm{L})$ +硫酸 $(300 \mathrm{ml} /$ L ) 混合溶液に30秒浸漬させ，水洗した後めっきを施 した。

\section{2 皮膜の物性測定と表面観察}

析出速度は重量法により算出し, 析出物中のリン の含有量は析出物を濃硝酸で溶解後, 高周波プラズ マ発光分析（ICP）で測定した。また, 走査型電子 顕微鏡（SEM）を用いて皮膜の外観の観察も同時に 行った。

この実験では, $96 \% \alpha$-アルミナセラミックスをめつ き素地として用い，七ラミックスの前処理工程とし て, $100 \mathrm{~g} / \mathrm{L}-\mathrm{NaOH}$ 溶液 $\left(40^{\circ} \mathrm{C}\right)$ で 5 分間処理し, 十分に水洗した後，5分間超音波洗浄を行った。つ いで, 表 2 に示した方法でセラミックス表面を触媒 化した ${ }^{6), 7)}$ 。

\section{3 析出物の熱処理に伴う結晶構造の变化}

めっき浴組成およびめっき条件を表 3 のように設 定し, 析出した無電解パラジウムーリン合金皮膜の 熱処理に伴う結晶構造の変化を, X 線回折により測 定した。

\section{4 析出皮膜の物性}

上述のような，基礎的実験結果によって得られた 析出皮膜物性の工業的適応性について, はんだ需れ

Table 2 Catalyzing process for ceramics.

\begin{tabular}{rccc}
\hline 1) & PEG-1000 $100 \mathrm{ppm}$ & $40^{\circ} \mathrm{C}$ & $5 \mathrm{~min}$. \\
$2)$ & Rinse & & \\
$3)$ & $0.05 \mathrm{~g} / \mathrm{L}-\mathrm{SnCl} 2$ & $40^{\circ} \mathrm{C}$ & $5 \mathrm{~min}$. \\
$4)$ & Rinse & & \\
$5)$ & $0.1 \mathrm{~g} / \mathrm{L}-\mathrm{PdCl} 2$ & $40^{\circ} \mathrm{C}$ & $5 \mathrm{~min}$. \\
$6)$ & Rinse & & \\
$7)$ & $0.05 \mathrm{~g} / \mathrm{L}-\mathrm{SnCl}_{2}$ & $40^{\circ} \mathrm{C}$ & $2 \mathrm{~min}$. \\
$8)$ & Rinse & & \\
$9)$ & $0.1 \mathrm{~g} / \mathrm{L}-\mathrm{PdCl} 2$ & $40^{\circ} \mathrm{C}$ & $2 \mathrm{~min}$. \\
$10)$ & Rinse & & \\
\hline
\end{tabular}

Table 3 Bath composition and plating conditions.

\begin{tabular}{cc}
\hline $\mathrm{PdCl}_{2}$ & $0.005 \mathrm{~mol} / \ell$ \\
$\mathrm{NaH}_{2} \mathrm{PO}_{2}$ & $0.060 \mathrm{~mol} / \ell$ \\
trien & $0.050 \mathrm{~mol} / \ell$ \\
$\mathrm{Tl}_{2} \mathrm{SO}_{4}\left(\mathrm{as} \mathrm{Tl}^{+}\right)$ & $10 \mathrm{ppm}$ \\
$\mathrm{pH}$ & 5 \\
Temperature & $60^{\circ} \mathrm{C}$ \\
Plating time & $1 \mathrm{~h}$ \\
Without agitation & \\
\hline
\end{tabular}


性試験, 接触抵抗測定, 摺動接触抵抗測定, 硬度測 定, 応力測定および耐食性試験を行った。

はんだ需れ性はメニスコグラフ法を用いて評価し， 接触抵抗の測定は 4 端子法で行い, 摺動接触抵抗は, 摺動ごと5000回後に接触抵抗を計測した。さらに, 摺動接触抵抗試験後の試験片側とプローブ側の両サ ンプルを走査型電子顕微鏡（SEM）で観察し，摺動 性について検討した。

パラジウムーリン合金めっきの膜厚は, はんだ下 地めっきを想定しためっき厚さ $0.1 \mu \mathrm{m}$, 接触部品へ の適用を想定しためっき厚さ $1.0 \mu \mathrm{m}$ で検討を行った。

析出皮膜の硬度測定は, ニッケル素地上に, 無電 解パラジウムーリン合金めっきを約 $3 \mu \mathrm{m}$ 施し, 軽荷 重微小硬度計により, 析出皮膜の熱処理に伴う硬度 の変化を測定した。熱処理温度の変化に伴う, パラ ジウムーリン合金皮膜の表面形態は SEM により観察 した。

さらに, 応力測定はストリップ電着応力測定器 (エ レクトロケミカル社製) で測定した。

而食性試験は, 塩水噴霧試験, $\mathrm{SO}_{2}$ ガス試験およ び混合 $\left(\mathrm{SO}_{2}+\mathrm{H}_{2} \mathrm{~S}\right)$ ガス試験の 3 種類の方法で評 価した。

\section{3. 実験結果および考察}

\section{1 めっき浴の安定性に及ぼす}

\section{各種パラメータの影響}

錯化剤選定の実験の結果, 表 4 に示すようにトリ エチレンテトラミンが最良であった。したがって, トリエチレンテトラミンを錯化剤として選定し，以

Table 4 Stability of bath with various complexing agents.

\begin{tabular}{c|cccc}
\hline & \multicolumn{4}{|c}{$\mathrm{R}$} \\
\cline { 2 - 5 } & 10 & 20 & 30 & 40 \\
\hline Ethylenediamine & $\triangle$ & $\triangle$ & $\triangle$ & $\triangle$ \\
Diethylenetriamine & $\times$ & $\times$ & $\times$ & $\times$ \\
Triethylenetetramine & $\bigcirc$ & $\bigcirc$ & $\bigcirc$ & $\bigcirc$ \\
Tetraethylenepentamine & $\times$ & $\times$ & $\times$ & $\times$ \\
Ammonium Chloride & $\times$ & $\times$ & $\times$ & $\times$ \\
Glycine & $\times$ & $\times$ & $\times$ & $\times$ \\
\hline
\end{tabular}

$\mathrm{R}$ : Complexing agent concentration/ $\mathrm{PdCl} 2$ concentration $\mathrm{O}:$ Good, $\triangle:$ Fair, $\times:$ Bad
下の実験を行った。

ついで, 安定剤の選定を行った結果, 表 5 のよう に有効な安定性を示したものは $\mathrm{Tl}_{2} \mathrm{SO}_{4}, \mathrm{Bi}_{2} \mathrm{O}_{3}$, $\mathrm{SeO}_{2}, \mathrm{~V}_{2} \mathrm{O}_{5}$ であった。

これらの安定剤の中で, $\mathrm{SeO}_{2}$ を添加すると皮膜が 黒色となり, $\mathrm{V}_{2} \mathrm{O}_{5}$ では密着不良が発生し， $\mathrm{Bi}_{2} \mathrm{O}_{3}$ で は析出速度が一定せず再現性に問題があったので, 本研究においては $\mathrm{Tl}_{2} \mathrm{SO}_{4}$ を安定剤として選定した。 $\mathrm{Tl}_{2} \mathrm{SO}_{4}$ が安定剤として効果のあった理由は, 無電解 金めっきへのタリウム添加効果 ${ }^{8)}$ と同様, パラジウム 触媒面にタリウムが吸着し, パラジウムの触媒性を 抑制するためであると考えられる。

\section{2 皮膜の物性と表面状態}

図 1 - $\mathrm{a}$ に示すように, パラジウムイオン濃度の 増加に伴い $1.5 \sim 3.8 \mu \mathrm{m} / \mathrm{h}$ に析出速度は増大した。一 方, 析出皮膜中のリンの含有量はパラジウムイオン 濃度の増加と共に4.5〜3.5 wt \%に低下した。

析出速度に及ぼす $\mathrm{pH}$ の影響は, $\mathrm{pH}$ 5 8の範囲 ではほほとんど認められなかった。また,リンの含 有量は $\mathrm{pH}$ が低いほど高い值を示した。しかし， pH が 4 以下になるとめっき浴が不安定になり, 浴分解 を引き起こして成膜が不可能となった。以上の結果 から, pH 5 〜 付近が浴安定性に優れていることが 確認できた（図 $1-\mathrm{c}$ )。

Table 5 Stability of bath with various addition agents.

\begin{tabular}{c|cccc}
\hline & \multicolumn{4}{|c}{$\mathrm{R}$} \\
\cline { 2 - 5 } & 2 & 10 & 20 & 30 \\
\hline $\mathrm{Tl}_{2} \mathrm{SO}_{4}$ & $\times$ & $\bigcirc$ & $\bigcirc$ & $\bigcirc$ \\
$\mathrm{SeO}_{2}$ & $\bigcirc$ & $\bigcirc$ & $\times$ & $\times$ \\
$\mathrm{PbCl}_{2}$ & $\times$ & $\bigcirc$ & $\times$ & $\times$ \\
$\mathrm{V}_{2} \mathrm{O}_{5}$ & $\bigcirc$ & $\bigcirc$ & $\bigcirc$ & $\bigcirc$ \\
$\mathrm{Bi}_{2} \mathrm{O}_{3}$ & $\times$ & $\bigcirc$ & $\bigcirc$ & $\bigcirc$ \\
$\mathrm{FeCl} 3$ & $\times$ & $\times$ & $\times$ & $\times$ \\
$\mathrm{Zn}\left(\mathrm{CH}_{3} \mathrm{COO}\right)_{2} \cdot 2 \mathrm{H}_{2} \mathrm{O}$ & $\times$ & $\times$ & $\times$ & $\times$ \\
$\mathrm{SeO} 2+\mathrm{Bi2O} 3$ & $\times$ & $\times$ & $\bigcirc$ & $\bigcirc$ \\
$2-\mathrm{Aminopyridine}$ & $\times$ & $\times$ & $\times$ & $\times$ \\
2,2 -Dipyridyl & $\times$ & $\times$ & $\times$ & $\times$ \\
PEG-1000 & $\times$ & $\times$ & $\times$ & $\times$ \\
Sucrose & $\times$ & $\times$ & $\times$ & $\times$ \\
Thiourea & $\times$ & $\times$ & $\times$ & $\times$ \\
\hline
\end{tabular}

$\mathrm{R}$ :Complexing agent concentration/ $\mathrm{PdCl} 2$ concentration $\bigcirc:$ Good, $\times:$ Bad 


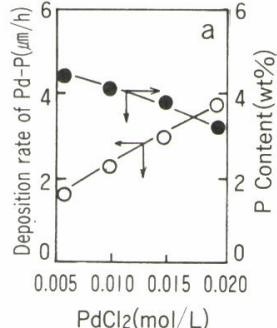

$\mathrm{PdCl} 2(\mathrm{~mol} / \mathrm{L})$
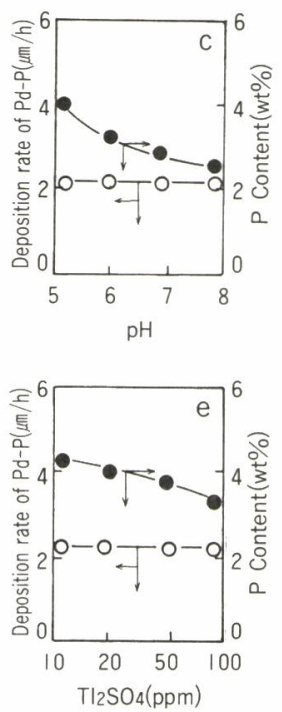

Fig.। Effects of bath composition and plating condition on deposition rate and $\mathrm{P}$ content.

また，皮膜の表面形態の観察結果を図 2 に示すが， $\mathrm{pH}$ が高く,リンの含有量が低いほどクラックの発生 が著しかつた。このように, クラックの発生は析出 皮膜のリンの含有量に依存し, リン含有量が低下す ると共に, パラジウムの水素吸蔵性が増大し, クラッ クが発生しやすくなると考えられる。

還元剤である次覀りン酸ナトリウム濃度の増加は, 析出速度およびリンの含有量を増大させるが, 次亜 リン酸ナトリウム濃度が $0.09 \mathrm{~mol} / \mathrm{L}$ 以下になると, 浴の安定性が低下し, 被めっき面以外での析出が起 こりやすくなった（図 1 - b)。

また，浴温の上昇に伴い析出速度とリンの含有量 がともに増大する傾向を示し（図 $1-\mathrm{d}$ ), 安定剂で ある $\mathrm{Tl}_{2} \mathrm{SO}_{4}$ 濃度の増加は, 析出速度にあまり影響し ないが, 析出皮膜中のリン含有量を減少させた（図 1 - e )。また，錯化剤であるトリエチレンテトラミ ンの濃度が $0.02 \sim 0.10 \mathrm{~mol} / \mathrm{L}$ の範囲では, 析出速度
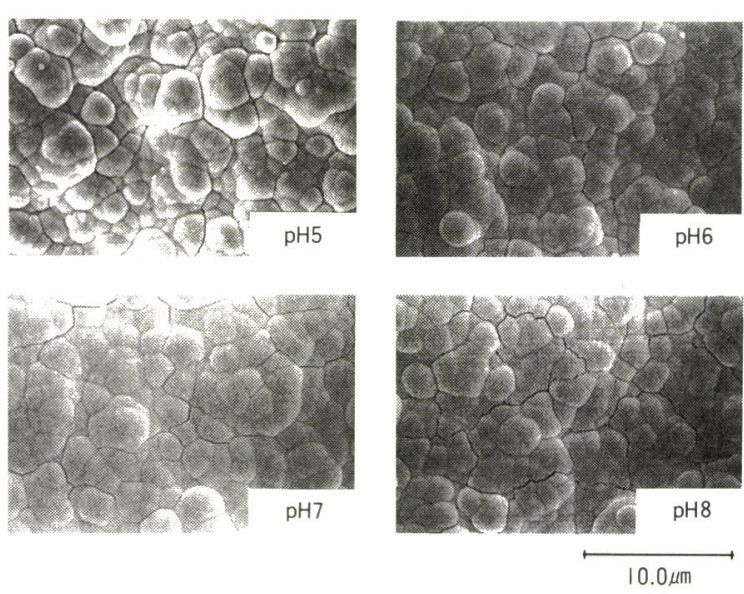

Fig.2 Effect of $\mathrm{pH}$ on surface morphology of electroless $\mathrm{Pd}-\mathrm{P}$ films.

とリンの含有量はともにほぼ一定值を示した（図 1 f)。

\section{3 析出物の熱処理に伴う結晶構造の変化}

以上の実験結果から，めっき浴組成拈よ゙めつき 条件を表 3 のように設定し, このめつき浴から析出 した無電解パラジウムーリン合金皮膜の熱処理に伴 う結晶構造の変化をX 線回折により測定し，その結 果を図 3 に示す。

熱処理前の無電解パラジウムーリンの合金皮膜は, 非晶質であり，Pd (111）面のブロードな回折線の

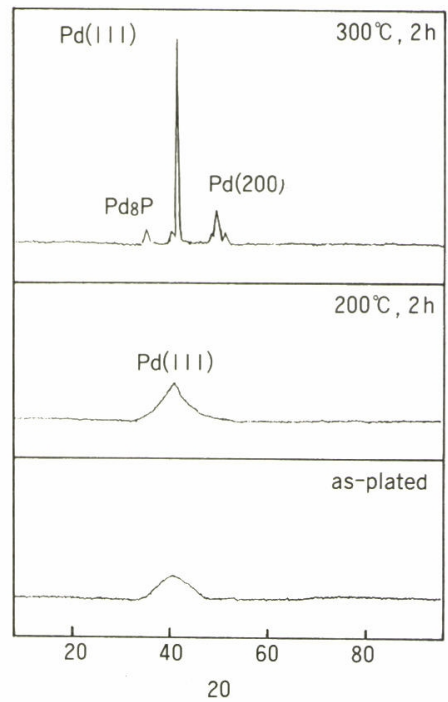

Fig.3 X-ray diffraction patterns of as-plated and heat treated electroless Pd-P films. 
みがめつき直後の皮膜で観察された。一方， $200^{\circ} \mathrm{C} の$ 熱処理を行った皮膜では, Pd (111) 面の結晶化が 進行するため, 小さなピークが観察され， $300^{\circ} \mathrm{C}$ 熱 処理を行った皮膜では，パラジウムの (111) 面，(200) 面の回折線の他に, $\mathrm{Pd} 8 \mathrm{P}$ の回折線 ${ }^{9}$ を確認すること ができた。

\section{4 析出皮膜の物性}

金属パラジウムは金属格子内に多量の水素を吸蔵 し，水素脆化を起こして脆くなる。無電解めっきで 析出したパラジウムもまた, 還元剤である次亜リン 酸ナトリウムの酸化反応時に発生する水素を析出パ ラジウム皮膜中にとりこむと考えられる。しかし， パラジウム皮膜は数 wt \%のリンを含んだパラジウムー リン合金であるため，金属パラジウムに比較すると， 水素の吸蔵性は低いであろう。しかし，銅やニッケ ルなどの無電解めっき皮膜に比べると水素の吸蔵性 は，はるかに高いと考えられる。したがって，この 還元剂の酸化反応時に生成する，水素を除去できれ ば，パラジウム皮膜の物性が改善される可能性があ る。

不飽和脂肪族のアルケン類のように，分子内に二 重結合を持つ化合物は, 容易に水素付加反応を起こ すことが知られている ${ }^{10)}$ 。したがって，めっき溶液
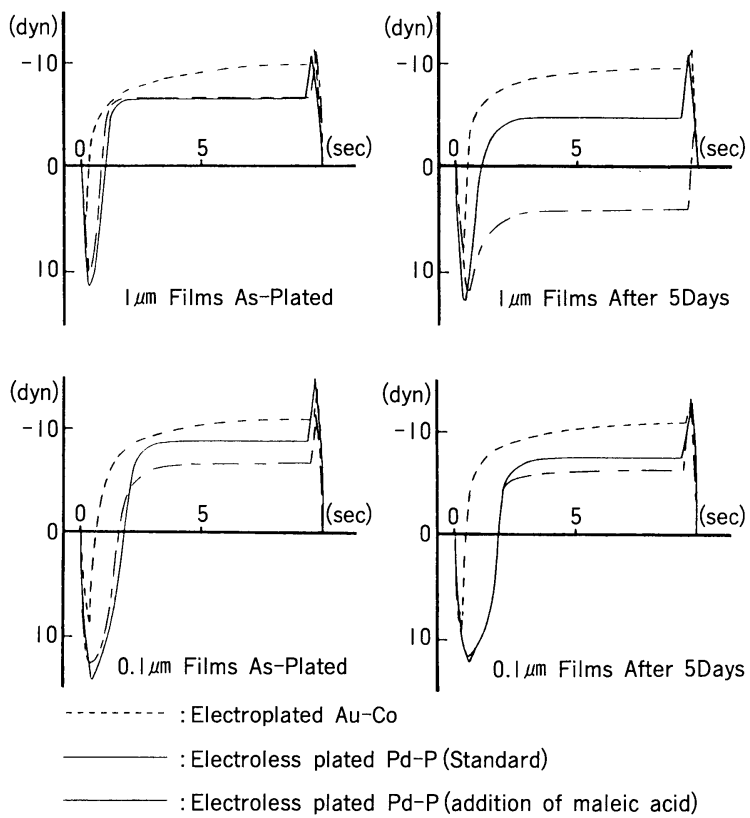

Fig.4 Time dependence of solderability.
中に，この種のアルケン類を添加することによって， めっき皮膜の触媒活性面で発生する水素の，皮膜中 へのとりこみを水素付加反応により抑制することが できると考えられる。

そこで, 不飽和脂肪族のアルケン類の代表として マレイン酸を選び，添加濃度を0.00〜 $0.12 \mathrm{~mol} / \mathrm{L}$ ま で変化させ検討した結果，成膜性にはあまり影響が なかったので，めっき浴への添加量を $0.09 \mathrm{~mol} / \mathrm{L} に$ 設定し，その添加効果についてはんだ濡れ性試験, 接触抵抗測定，摺動接触抵抗測定，硬度測定，応力 測定および耐食性試験を行い，析出皮膜の工業的適 応性を評価した。

\section{4 .1 はんだ濡れ性}

はんだ濡れ性の評価を行った結果を図 4 に示す。 めつき直後の無電解パラジウムーリン合金皮膜は, 金のはんだ需れ性に比べると，多少劣るものの良好 なはんだ需れ性を示した。また，5日後のはんだ需 れ性試験において，マレイン酸添加浴から得られた 皮膜は, マレイン酸無添加浴から得られた皮膜に比 べて，良好なはんだ濡れ性を示した。そして，その 傾向は析出皮膜の膜厚が厚いほど顕著であった。

\section{4 .2 接触抵抗}

接触抵抗の測定を行った結果を図 5 に示す。パラ

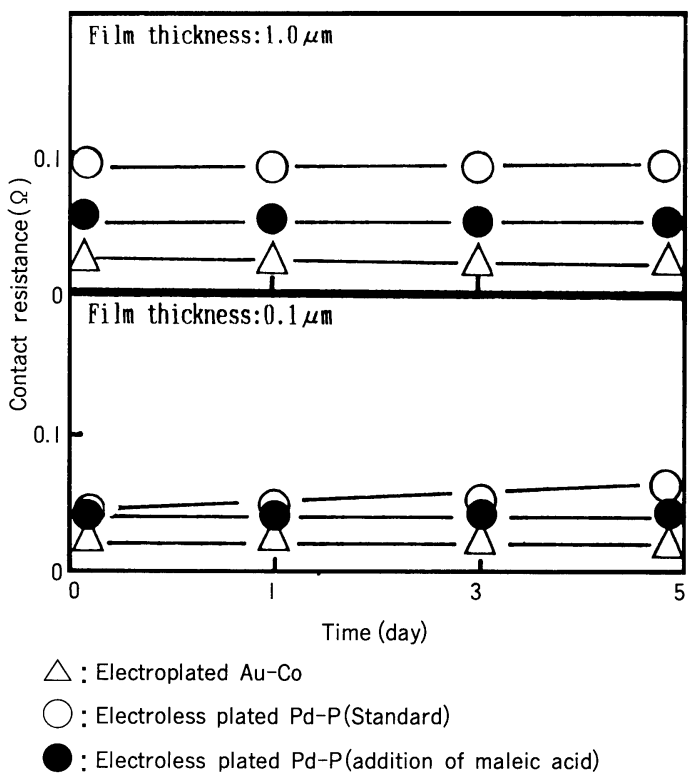

Fig.5 Changes in contact resistance of various films. 
ジウムーリン合金めつきの膜厚が $0.1 \mu \mathrm{m}$ 場合，接触 抵抗値はマレイン酸添加の有無に関係なく，金に類 似した值を示し, 経時変化も小さかった。しかし, めっき膜厚が $1.0 \mu \mathrm{m}$ の場合は, マレイン酸添加の効果 は顕著であり, 比較的低い接触抵抗值が維持され, 経時変化も小さくなる傾向を示した。

\section{4 .3 摺動接触抵抗}

摺動後の接触抵抗は図 6 より, マレイン酸無添加 浴から得られた皮膜よりも，マレイン酸添加浴から 得られた皮膜の方が低い值を示した。

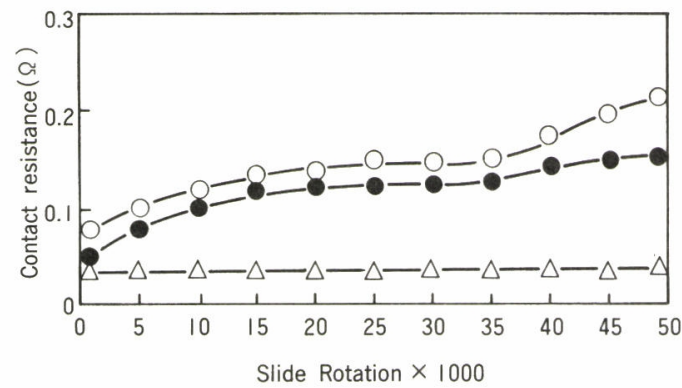

$\triangle$ : Electroplated $\mathrm{Au}-\mathrm{Co}$

$\mathrm{O}$ : Electroless plated $\mathrm{Pd}-\mathrm{P}$ (Standard)

- Electroless plated Pd-P(addition of maleic acid)

Fig.6 Relation between sliding damage and contact resistance.
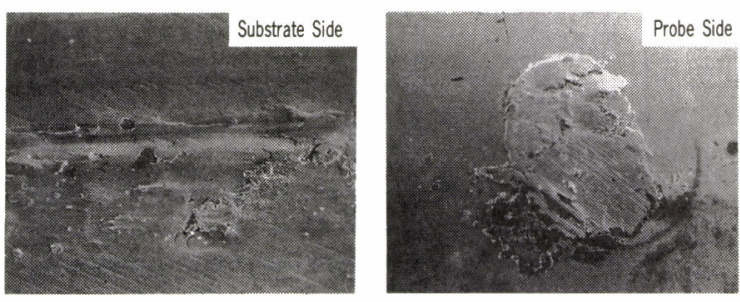

$\longleftarrow 20 \mu \mathrm{m}$

Electroless plated Pd-P (Standard)

$100 \mu \mathrm{m}$
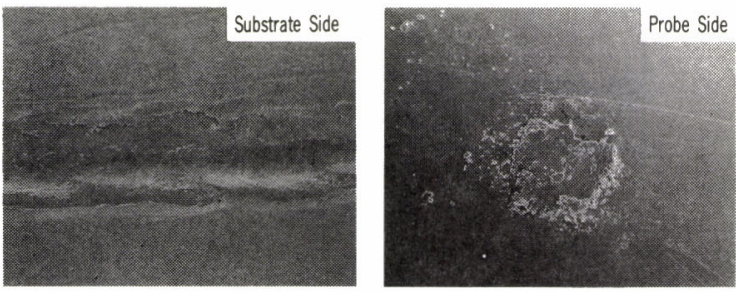

20

Electroless plated Pd-P (addition of maleic acid)

$100 \mu \mathrm{m}$

Fig.7 SEM photographs of $P d-P$ film and probe after sliding damage test.
また，摺動後の試験片とプローブの両方の SEM 写 真より (図 7 ), マレイン酸を添加しなかったパラジ ウムーリン合金皮膜の摺動痕は脆く, 多数のはく離 個所が認められた。これは，析出皮膜が水素を吸蔵 し, 脆くなるためと考えられる。一方, マレイン酸 を添加した浴から得られた皮膜は，摺動痕が平滑で あり，パラジウムーリン合金皮膜に柔軟性があるこ とが推定される。

\section{4 .4 硬度測定}

マレイン酸添加浴および無添加浴から析出したパ ラジウムーリン合金皮膜の硬度を測定し，比較した 結果を図 8 に示す。マレイン酸添加浴から得られた 皮膜と, マレイン酸無添加浴から得られた皮膜の硬 度は,めつき直後ではほぼ同じ值を示した。また， 熱処理に伴う析出皮膜の硬度の変化について検討し た結果，マレイン酸無添加浴からのパラジウムーリ ン合金めっき皮膜の硬度は， $300^{\circ} \mathrm{C}$ 付近で最大值を示 し，それ以上の温度で熱処理を施すと減少した。こ れは， $300^{\circ} \mathrm{C}$ 付近でパラジウムーリン合金が結晶化を 起こし，硬度が増加することに基づいている3”。また， 電析パラジウムめっき皮膜も $300^{\circ} \mathrm{C}$ 付近で硬度が最大 となり，それ以上の温度では減少する傾向を示した が，この熱処理による硬度の変化について，Raubら は，熱処理によって皮膜内にとりこまれた水素が急 速に除去され, いったん, 引張応力と硬度が増加す

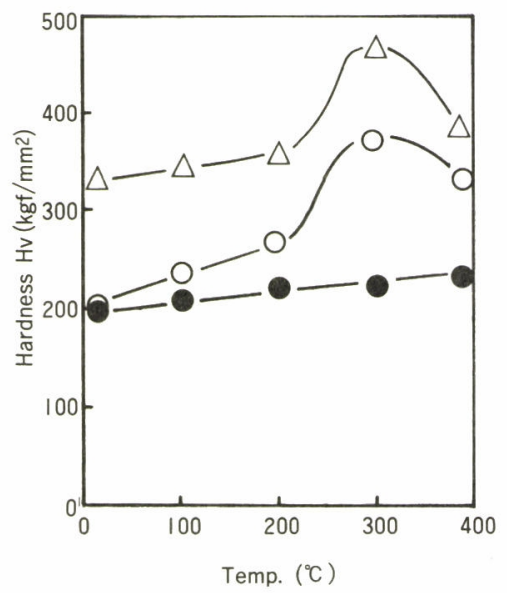

$\triangle$ : Electroplated Pd

$O$ : Electroless plated $\mathrm{Pd}-\mathrm{P}$ (Standard)

- Electroless plated Pd-P(addition of maleic acid)

Fig.8 Changes in Vickers hardness with heat treatment of Pd film. 
るが, さらに熱処理温度が上昇すると, 結晶格子の 乱れが回復し，硬度が減少するとしている ${ }^{11)} 。$ 一方， マレイン酸添加浴から得られた析出皮膜の硬度が, 熱処理によってあまり変化しないのは, 水素のとり こみや，リンの共析が少ないことに基づくと考えら れる。

熱処理温度の変化に伴う, パラジウムーリン合金 皮膜の表面形態観察を行った結果を図 9 に示す。熱 処理前のマレイン酸無添加浴から得られた析出皮膜 は, 多数の凝集粒子が観察された。マレイン酸添加 浴から得られた皮膜は, 析出粒子が微結晶化し, 電 析パラジウムめっき皮膜と類似した形態が観察され た。また, $300^{\circ} \mathrm{C}$ 熱処理を 2 時間施した後の析出形 態は, マレイン酸無添加浴から得られた皮膜では結 晶化に伴って粒子が微細化した。一方，マレイン酸 添加浴から得られた析出皮膜は, 電気めっきで得ら れた皮膜と同様, 熱処理による結晶形態の変化はあ まり見られなかった。

\section{4 .5 応力測定}

析出皮膜の応力について測定した結果, 電析パラ ジウム皮膜の応力は $72.7 \mathrm{~kg} / \mathrm{mm}^{2}$, マレイン酸無添加

Electroless plated $\mathrm{Pd}-\mathrm{P}$ (Standard)

Electroless plated $\mathrm{Pd}-\mathrm{P}$ (addition of maleic acid)

Electroplated Pd
As-Plated
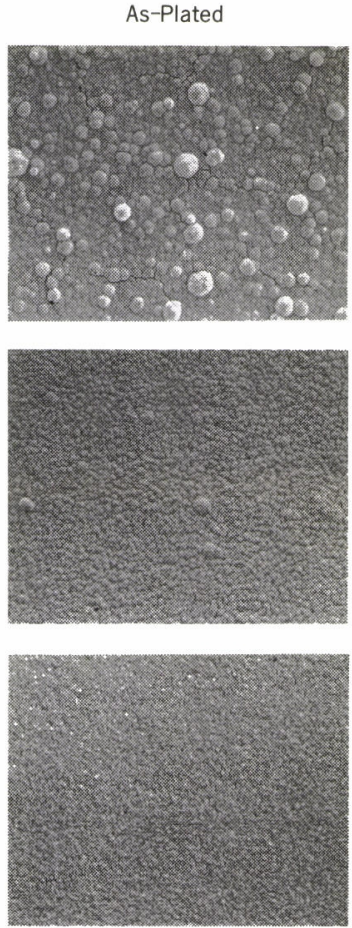

浴からの析出皮膜は $5.8 \mathrm{~kg} / \mathrm{mm}^{2}$, また, マレイン酸 添加浴からの皮膜では $3.6 \mathrm{~kg} / \mathrm{mm}^{2}$ を示した。このよ うに、析出皮膜の応力は電析めっき皮膜よりも, 無 電解めっき皮膜の方がはるかに低い值を示したが, これは, 電気めっき皮膜と比較して水素の吸蔵性が 低いこと，抒よび析出皮膜が非晶質であることに基 づいていると考えられる。また, マレイン酸添加浴 から得られた皮膜は, マレイン酸無添加浴から得ら れた皮膜よりもさらに低い応力を示した。

\section{4 .6 耐食性試験}

而食性試験は塩水噴霧試験， $\mathrm{SO}_{2}$ ガス試験および 混合 $\left(\mathrm{SO}_{2}+\mathrm{H}_{2} \mathrm{~S}\right)$ ガス試験の 3 種類の方法で評価 し，その結果を図10に示す。

図10より，パラジウムーリン合金皮膜が1.0umでは， 3 種類いずれの耐食性試験においても，マレイン酸 添加浴から得られた皮膜はマレイン酸無添加浴から 得られた皮膜よりも，良好な耐食性を示した。

パラジウムーリン合金皮膜の物性について, 以上 の方法に基づいて評価したが，いずれの評価結果か らもマレイン酸を添加した浴から析出したパラジウ ムーリン合金皮膜は，はんだ需れ性，接触抵抗，摺

Heat Treatment $\left(300^{\circ} \mathrm{C}, 2 \mathrm{~h}\right)$
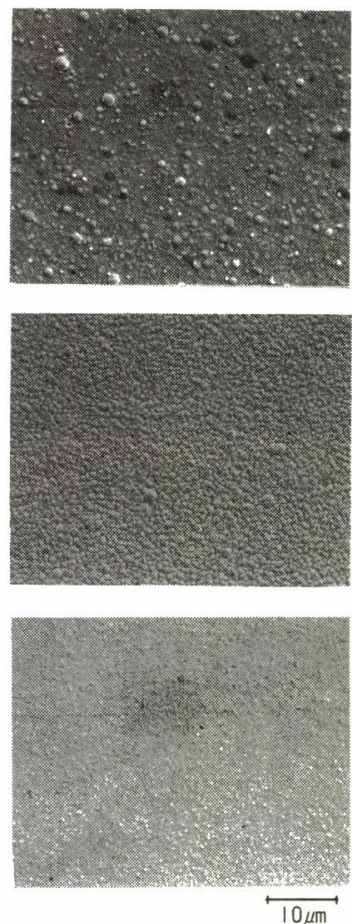

Fig.9 Surface morphology of Pd films from various plating baths. 
動性，硬度，応力，耐食性を向上させた。

\section{4. 結 論}

次亜リン酸ナトリウムを還元剤とする無電解パラ ジウムーリン合金めつきについて基礎的な研究を行っ た結果, 錯化刻としては, トリエチレンテトラミン が，また，安定剤としては， $\mathrm{Tl}_{2} \mathrm{SO}_{4}$ が有効であった。 パラジウムーリン合金めっきの析出速度並びにリ ンの含有量は, めっき浴中のパラジウムイオン濃度 と $\mathrm{pH}$ によりきく変化した。

析出した無電解パラジウムーリン合金皮膜は X 線 回折の結果, 非晶質であり Pd (111) 面のブロード

Electroless plated Pd-P

(standard)
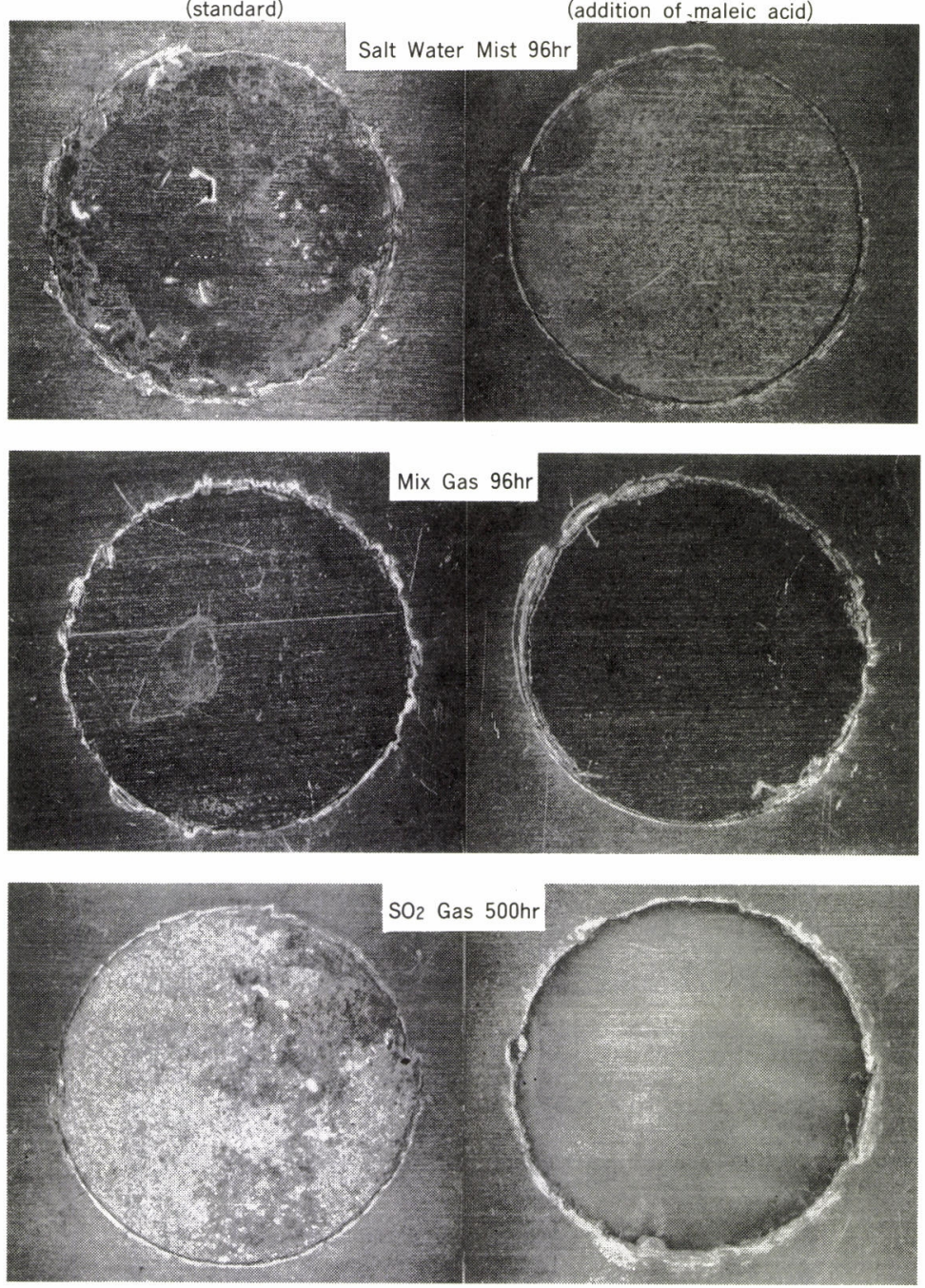

Fig.I0 Microphotographs for the electroless plated Pd-P films after corrosion test. 認することができた。 Electroless plated Pd-P

(addition of, maleic acid)

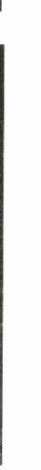

な回折線がめっき時の皮膜から観察された。一方， $200^{\circ} \mathrm{C}$ 熱処理を行うことにより，Pd（111）面の結 晶化が進行し，小さなピークが観察された。さらに， $300^{\circ} \mathrm{C}$ 熱処理を行った皮膜では，パラジウムの（111） 面，(200）面の回折線の他に, $\mathrm{Pd} 8 \mathrm{P}$ の回折線を確

析出皮膜の物性をはんだ濡れ性, 接触抵抗, 替動 接触抵抗, 硬度測定, 応力測定, 耐食性試験の 6 項 目の実験を行った結果，マレイン酸（アルケン類の 代表として）添加浴から得られた無電解パラジウムー リン合金めっき皮膜は，マレイン酸無添加浴から得 られた皮膜と比較して，いずれの項目についても物 
性の向上が確認された。

以上，無電解パラジウムーリン合金めっきについ て基礎的な検討を行ったが，パラジウムはその性質 上，電子部品への応用が大いに期待される。

(1991.12.19-受理)

\section{文}

\section{献}

1) 縄舟秀美：“無電解パラジウムめっきの現状と将来”， 表面技術，42, 37 (1991)

2 ) S. Uemiya, Y. Kude, K. Sugino, N. Sato, T. Matsuda, E. Kikuchi: "APalladium /Porous-Glass Composite Membrane for Hydrogen Separation", Chem. Lett., 1687 (1988)

3 ）水本省三, 縄舟秀美, 内田衛, 芳賀正記：“エチレ ンジアミン錯体浴からの無電解Pd-P合金めっき”, 表面技術，40，477（1989）

4 ）水本省三, 縄舟秀美, 内田衛, 芳賀正記： “無電解 $\mathrm{Pd}-\mathrm{Ni}-\mathrm{P}$ 合金めっきとその皮膜特性”，表面技術，40， 688 (1989)

5 ）芳賀正記, 内田衛, 水本省三, 縄舟秀美 : “無電解 $\mathrm{Pd}-\mathrm{P}$ 合金めっき皮膜のはんだ付け性および接触抵抗”，
表面技術，42，262（1989）

6 ) H. Honma, K. Kanemitu: "Electroless Nickel Plating on Alumina Ceramics", Plating and Surf. Fin., 74, $62(1987)$

7 ) H. Honma, Y. Kouchi: "Direct Electroless Copper Plating on Alumina Ceramics", Plating and Surf. Fin., 76, 58 (1989)

$8)$ M. Matsuoka, S. Imanishi, M. Sahara, T. Hayashi: "Heavy Deposition of Electroless Gold", Plating and Surf. Fin., 75, 102 (1988)

9) Powder Diffraction File 19-888 (1979) , JCPDS International Center

10) G. Linka, W. Ridel: "Korrosionsbestandigkeit von chemisch-rduktiv abgeschiedenen NickelPhosphor-Legierungsuberzugen als Funktion des Badalters”, Galvanotechnik., 77, 568 (1987)

11) D. H. Hedrich, J. Ch. Raub: "Untersuchungen zur galvanischen Palladium-abscheidung auszusatfreien, ammonialkalischen Elektrolyten", Surf. Technol, 8, 347 (1979) 